\title{
Foreign body mimicking a herpes simplex dendritic ulcer in the cornea
}

\author{
Damien Chia Ming Yeo
}

Department of Ophthalmology, Singleton Hospital, Swansea, UK

\section{Correspondence to} Dr Damien Chia Ming Yeo, cm.yeo@doctors.org.uk
To cite: Yeo DCM. BMJ Case Rep Published online: [please include Day Month Year] doi:10.1136/bcr-2013200143

\section{DESCRIPTION}

A 49-year-old woman presented to the eye casualty department after referral from her general practitioner for a painful red eye since morning. She had a unilateral injected right eye with associated lid swelling. Visual acuity was reduced at 6/24 in the right eye.

An initial slit lamp examination by the senior house officer picked up a dendritic-like lesion in the cornea just inferior to the visual axis. The initial suspicion was a herpes simplex infection especially with the reduced visual acuity and the discomfort (figure 1).

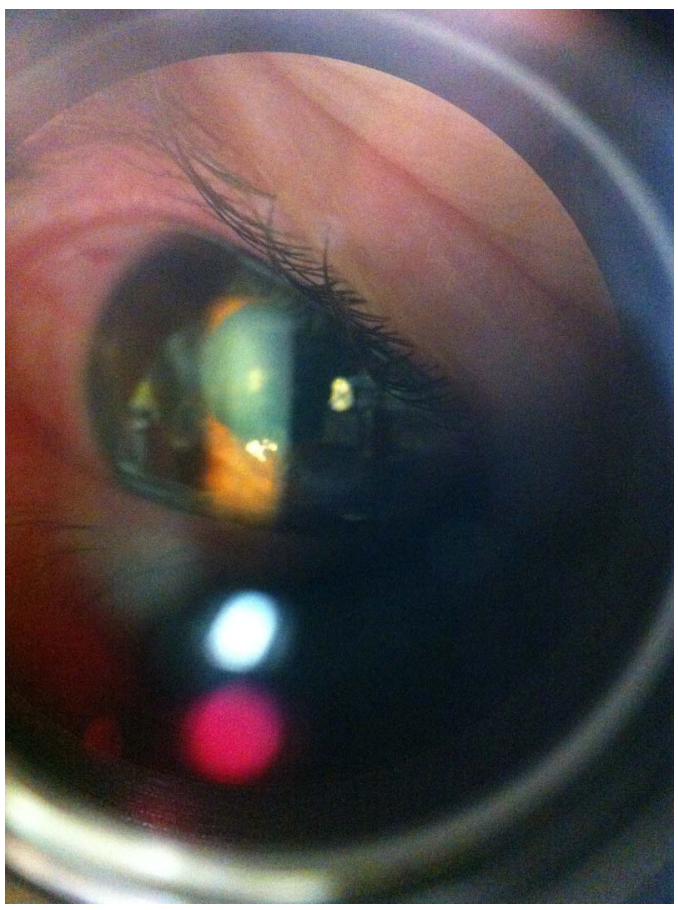

Figure 1 A pseudodendritic lesion on the cornea.
A second examination by the ophthalmic registrar found the lesion to be atypical. It certainly resembled a dendritic lesion macroscopically but high magnification using the slit lamp revealed a shiny surface. When the patient was questioned directly, she remembers coming in contact with some glitter from a Christmas card. Interestingly, the glitter had formed itself in a clump that mimicked the shape of a dendritic ulcer. Fluorescein staining also showed additional uptake across the lesion. This foreign body was removed from the surface of the cornea and the patient was discharged on topical antibiotic treatment.

In this instance, the patient was fortunate to have presented in the ophthalmic casualty department. The lesion may have been easily misdiagnosed as a herpetic simplex infection by non-specialists for which treatment would have been topical antiviral ointment instead of removal and antibiotics. It is therefore important to always remember to inquire specifically about possible trauma (however unlikely) in any lesions of the eye.

\section{Learning points}

- Always include a trauma history in any lesions of the eye.

- Consider a senior review for any cases that look atypical especially if the condition is still new to you.

- There are also other infective and non-infective causes for a pseudodendritic corneal lesion.

\section{Competing interests None.}

Patient consent Obtained.

Provenance and peer review Not commissioned; externally peer reviewed.

Copyright 2013 BMJ Publishing Group. All rights reserved. For permission to reuse any of this content visit

http://group.bmj.com/group/rights-licensing/permissions.

BMJ Case Report Fellows may re-use this article for personal use and teaching without any further permission.

Become a Fellow of BMJ Case Reports today and you can:

- Submit as many cases as you like

- Enjoy fast sympathetic peer review and rapid publication of accepted articles

- Access all the published articles

- Re-use any of the published material for personal use and teaching without further permission

For information on Institutional Fellowships contact consortiasales@bmjgroup.com

Visit casereports.bmj.com for more articles like this and to become a Fellow 